\title{
Dog Bites and Their Treatment in Federation of Bosnia and Herzegovina
}

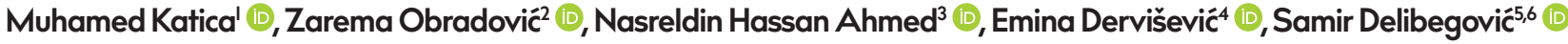 \\ 'Department of Pathophysiology, Sarajevo University Veterinary Faculty, Sarajevo, Bosnia and Herzegovina \\ ${ }^{2}$ Deparment of Enviromental Health-Epidemiology, Sarajevo University School of Health Studies, Sarajevo, Bosnia and Herzegovina \\ ${ }^{3}$ Emergency Medicine Clinic, University Clinical Center Sarajevo, Sarajevo, Bosnia and Herzegovina \\ ${ }^{4}$ Department of Forensic Medicine, University of Sarajevo, School of Medicine, Bosnia and Herzegovina \\ ${ }^{5}$ Surgery clinic, University Clinical Center Tuzla, Bosnia and Herzegovina \\ ${ }^{6}$ Department of Surgery, University of Tuzla, School of Medicine, Bosnia and Herzegovina
}

ORCID IDs of the authors: M.K. 0000-0002-8I84-0065; Z.O. 0000-0003-458I-5863; N.H.A. 0000-0002-72I9-5324; E.D. 0000-000I-84290508; S.D. 0000-0003-0525-3288.

Cite this article as: Katica M, Obradović Z, Ahmed NH, Dervišević E, Delibegovic S. Dog Bites and Their Treatment in Federation of Bosnia and Herzegovina. Cyprus J Med Sci 2019; 4(2): 136-40.

\begin{abstract}
Cohabitation of humans and dogs often results in dog bites that may lead to severe health risks due to viral, bacterial, and parasitic zoonoses. Dog bites result in wounds and the dysfunction of damaged tissues, as well as possible infection, alongside the risk of rabies and tetanus, if appropriate and timely treatment is not administered. Pediatric and geriatric patients, as well as pregnant women, are the most vulnerable categories, being the most susceptible to psychological trauma. Research results suggest that in the Federation of Bosnia and Herzegovina (FB\&H) during the 1996-2005 period, there were 6.9\% more bites inflicted by dogs of known owners compared to the number of bites inflicted by stray dogs, but during the 2006-2010 period, this the percentage increased in favor of stray dogs. Dog bites are a serious social problem and pose a potential health risk due to viral, bacterial, parasitic, and fungal zoonoses. Timely and adequate treatment of bite wounds and the implementation of rabies-postexposure prophylaxis can significantly reduce health risks in patients who have suffered dog bites.
\end{abstract}

Keywords: Stray dogs, dogs of known owners, dog bite wounds, microorganisms in the canine oral cavity

\section{INTRODUCTION}

It is estimated that approximately 2 million people worldwide visit a doctor every year due to bite wounds caused by dogs and cats. Although there are no accurate statistical data, the importance and consequences of these injuries should not be underestimated (I). Under certain circumstances, dogs attack indiscriminately.

In the United States, more than ten deaths per year occur due to dog bites. Most of the victims are children (2-4). Children are a particularly vulnerable population group $(5,6)$. It is interesting to note that $78 \%$ of dog bites in children occur on the head and neck, which is particularly dangerous due to the location of the bite. The primary risk relates to the cessation of the cervical carotid artery continuity because this leads to certain death. The cause of wounds on these parts of the body is usually associated with children's short stature. Also, children often play with dogs and bring their heads close to the dog's, thus making their lips, nose, and cheeks the central "target area" $(7,8)$. Head bites are especially risky if they are caused by a rabid animal because the rabies virus spreads through the nervous system reaching the brain, and the disease develops fast. Especially dangerous are dog bite injuries to human genital organs $(9,10)$. Although there is no clearly identifiable target group in the sense of specific occupations, mail carriers often seem to be more vulnerable. Morgan and Palmer (II) estimate that 5.000 postal workers seek medical assistance due to dog bites in the United Kingdom every year. Despite numerous studies, it is difficult to prove exactly why dogs bite, at what point, and what profile of person is particularly at risk. There are several reasons for the aggressive behavior in dogs, and most important are the protection of their puppies, guarding of their territory, and the search for food. A high population density as well as the number of people moving about in some areas are the most common factors that lead to an increase in dog aggression and the number of bites (12-16). Almost half of all dog bites occur within the family where the dog lives. Dogs may bite their owners, close family members, or neighbors $(4,17)$. A significant number of dogs of known owners attack people in urban and 
public areas due to the irresponsible behavior of their owners $(18,19)$. Some dog breeds (Bull Terrier, German Shepherd Dog, Cocker Spaniel, Pit Bull, Collie, Rottweiler, Doberman Pinscher, and Siberian Husky) have been identified as more aggressive dog breeds than others (4,20-23). However, all dogs may exhibit aggressive behavior under certain circumstances (22). Alongside registered dogs, in countries undergoing transition and the regions with a war in their past, there is also a population of stray dogs. After their owners abandon them, dogs who are used to a certain lifestyle find themselves in a very confusing state. The loss of human support causes a number of problems, from territorial status to food security. Existential threats activate self-preservation mechanisms and a return to natural patterns of behavior, resulting in various unwanted events. Uncontrolled movement of dogs on roads causes traffic accidents, dogs usurp peace in the communities by barking, and they often attack people in a crowd, while their bites cause physical and mental harm (18). Several hundred different types of bacteria have been isolated from the canine oral cavity, and in their saliva, on their tongues, and gums (24-29). These are related to dogs of known owners who had, to a greater or lesser extent, health and veterinary care. A higher quantitative and qualitative representation of the bacterial population in the oral cavity of the stray dog population without any veterinary supervision is to be expected. After a dog bite, what usually occurs are minor lesions, for which no medical help is required. Dogs have rounded teeth and during the bite, their jaws pressurize, which may cause significant damage to the tissue (on the skin, muscles, tendons, blood vessels, nerves) (14). Dog bites may lead to severe infections of the wound with systemic complications and lead to prolonged disabling if not treated properly $(26,30-33)$. Microorganisms isolated from infected bite wounds are similar to those isolated from the oral cavity (34). The importance of the risk of infection of bite wounds is particularly emphasized: an

\begin{tabular}{|c|c|c|c|c|}
\hline Cantons & $\begin{array}{l}\text { Cantonal } \\
\text { area } \mathrm{km}^{2}\end{array}$ & $\begin{array}{l}\text { Population } \\
\text { density }\end{array}$ & $\begin{array}{l}\text { Number of } \\
\text { stray dogs }\end{array}$ & $\begin{array}{l}\text { Density of } \\
\text { stray dogs }\end{array}$ \\
\hline Tuzla & 2649 & 187.9 & 4500 & 1.69 \\
\hline Zenica-Doboj & 3.334 & 119.9 & 10000 & 2.99 \\
\hline Herz-Neretva & 4.401 & 51.5 & 3300 & 0.75 \\
\hline Sarajevo & 1.276 & 329.9 & 4000 & 3.13 \\
\hline Total & 11660 & Average 172.3 & Total 21800 & Average 2.14 \\
\hline
\end{tabular}

infection by rabdovirus from the Lyssavirus family and by tetanus spores, as well as the subsequent development of these diseases. For these reasons, all dog bites should be treated in a timely and adequate manner (I5).

\section{Epidemiological Aspects of Dog Bites in the Federation of Bosnia and Herzegovina}

The bites of different animals are not uncommon, and almost as a rule, they pose a problem to both the person who was bitten and the health system. Approximately $90 \%$ of animal bites are caused by dogs and cats (35). In Bosnia and Herzegovina $(B \& H)$, like in most areas of the world, the largest number of bites is inflicted by dogs and cats. According to the current Law on the Protection of the Population from Infectious Diseases in the $F B \delta H$, every animal bite must be registered by the ordinating physician and reported to the primary-level epidemiological services. From this point, an application is sent to the epidemiological services at the secondary level (the Public Health Department of the Canton) and is further transmitted to the tertiary level (the Public Health Institute of the FB\&H) (36). However, many bitten persons, especially those with minor injuries, do not seek medical help, so many bites remain unregistered. As a result, the actual number of people injured is certainly much higher than the number of registered bites. These injuries are caused by dogs living alongside humans as domestic animals or pets. However, there is another category of dogs, which are those who do not have an owner, so-called street dogs or stray dogs. The number of these dogs in B\&H increased considerably in the post-war period. Their presence is evident, primarily in urban, but also in rural areas of $\mathrm{B} \& \mathrm{H}$, and this has an adverse effect on the health of the population (18). One of the health risks are bites by this dog category. Although there is no difference between the bites of stray dogs and the bites of dogs that have an owner, the bites of stray dogs are more problematic when it comes to the potential risk of rabies because these dogs are often not

\begin{tabular}{lccc|}
\hline $\begin{array}{l}\text { TABLE 3. Attack rates by cantons in FBटH. Study performed in the } \\
\text { period 2008-2009 (12) }\end{array}$ & $\begin{array}{c}\text { Number of } \\
\text { stray dogs }\end{array}$ & $\begin{array}{c}\text { Number of } \\
\text { people bitten }\end{array}$ & Attack rate \\
\hline Cantons & 4500 & 1749 & 38.9 \\
\hline Tuzla & 10000 & 796 & 1.26 \\
Zenica-Doboi & 3300 & 243 & 7.36 \\
Herz-Neretva & 4000 & 1613 & 40.32 \\
Sarajevo & 21800 & 4401 & Average 20.18 \\
Total & & &
\end{tabular}

TABLE 2. Number of people bitten, presented by canton in FBᄃ̆H (18)

\begin{tabular}{|c|c|c|c|c|c|c|c|c|c|}
\hline \multirow[b]{2}{*}{ Year } & \multicolumn{8}{|c|}{ CANTONS } & \multirow[b]{2}{*}{ Total } \\
\hline & $N$ & Bites/100000 inhab & $\mathrm{N}$ & Bites/100000 inhab & $N$ & Bites/100000 inhab & $N$ & Bites/100000 inhab & \\
\hline 2014 & 450 & 101 & 165 & 45 & 51 & 22 & 483 & 117 & 1149 \\
\hline 2015 & 410 & 92 & 242 & 66 & 75 & 33 & 385 & 93 & 1112 \\
\hline Total & 1749 & Average & 796 & Average & 243 & Average & 1613 & Average & 4401 \\
\hline
\end{tabular}


TABLE 4. Comparison of a 4-year period of dog bites in Sarajevo (BdH), Zagreb (Croatia), and Belgrade (Serbia) $(12,19,38)$

\begin{tabular}{|c|c|c|c|c|c|c|c|}
\hline \multirow[b]{2}{*}{ Year } & \multicolumn{3}{|c|}{ Sarajevo } & \multirow{2}{*}{$\frac{\text { Zagreb }}{\text { Total dog bites }}$} & \multicolumn{3}{|c|}{ Belgrade } \\
\hline & Stray dog bites & Owned Dogs' bites & Total dog bites & & Stray dog bites & Owned dogs' bites & Total dog bites \\
\hline 2003 & 58 & 68 & 126 & 889 & 1694 & 748 & 2442 \\
\hline 2005 & 99 & 60 & 159 & 865 & 1509 & 1056 & 2565 \\
\hline 2006 & 119 & 63 & 182 & 802 & 1482 & 947 & 2429 \\
\hline
\end{tabular}

TABLE 5. Bacterial microflora in 50 infected dog bite wounds in

\section{humans $(26,29,46)$}

\begin{tabular}{lcll|}
$\begin{array}{l}\text { Type of } \\
\text { bacteria }\end{array}$ & $\begin{array}{c}\text { Percentage of } \\
\text { wound presence (\%) }\end{array}$ & $\begin{array}{l}\text { Type of } \\
\text { bacteria }\end{array}$ & $\begin{array}{c}\text { Percentage of } \\
\text { wound presence (\%) }\end{array}$ \\
\hline Pasteurella & 50 & Escherichia coli & 6 \\
Streptococcus & 46 & Klebsiella & 4 \\
Staphylococcus & 46 & Lactobacillus & 4 \\
Neisseria & 32 & Citrobacter & 4 \\
Corinebacterium & 12 & Flavobacterium & 4 \\
Moraxella & 10 & Micrococcus & 4 \\
Enterococcus & 10 & Proteus mirabilis & 4 \\
Bacillus & 8 & Capnocytophaga & 2 \\
Pseudomonas & 6 & Eikenella corrodens & 2 \\
Actinomyces & 6 & Flavimonas & 2 \\
Brevibacterium & 6 & Stomatococcus & 2 \\
\hline
\end{tabular}

vaccinated, and if they are, the vaccination data are difficult to find. In addition, these dogs cannot be placed under the I0-day veterinary supervision, while this is done with dogs who have an owner. In some FB\&H cantons, during the 1996-2005 period, there were 1260 stray dog bites and three bites inflicted by dogs with known owners, that is, $6.9 \%$ more bites inflicted by dogs of known owners compared to the number of bites from stray dogs (37). The bites of dogs who have owners indicate the insufficient education of their owners. The percentage of dog bites, in relation to whether the dogs are stray animals or have owners, changed in the FB\&H over the 2006-20I0 period, where the percentage increased in favor of stray dogs. The reason for this was an enormous increase in the population of stray dogs following the Animal Welfare Act, with the local government bodies being unprepared to provide enough shelters for these abandoned animals $(12,37)$. The following table I shows data on stray dogs in several cantons in FB\&H.

Table I and 2 show that the largest number of bites is in areas with a higher population density, which corresponds to the results by Heath and Chomel (I3).

The frequency of dog bites in the mentioned cantons of the FB\&H differed. It ranged from I.26 (in the Zenica-Doboj Canton) to 40.2 (Sarajevo Canton) (Table 3). A similar situation occurred in Belgrade (Serbia) where the average number of dog bites was 148.48 per 100,000 inhabitants in the 2003-2006 period (19). The reasons for the higher dog bite rate per 100,000 inhabitants in relation to Sarajevo Canton should be seen in the fact that Belgrade has a greater population density, as well as a larger number of dogs, both those of known owners and stray dogs, which ultimately leads to a greater number of bites (Table 4). In Zagreb (Croatia), during the 1996-2005 period, a total of 10.177 people were physically inspected after injuries (bites, scratches) inflicted by dogs, cats, jackals, and other domesticated and exotic animals. In the observed period, 2003-2006, dogs bit, on average, 864.5 persons a year (38) (Table 4).

Reports from the Greek province of Macedonia indicate a high incidence of dog bites, much higher than that involving other animals (cats, horses). In this study, during the 1989-2009 period, the geriatric population of people aged $>65$ years was the most vulnerable to dog bites (39). In a similar study from 2006-2010, 328 cases of dog bites were recorded in western Turkey. Out of this number, $48 \%$ were in the population of young people aged $0-18$ (9).

\section{The Most Susceptible Groups}

Anybody may be bitten, but there are still people who are at greater risk. People who own dogs, especially if they have a larger number of domestic dogs, are at greater risk of bites than those who do not own them. Men are more commonly bitten than women (40). This ratio is different in different studies. In the aforementioned research in India, $64 \%$ of the people bitten were men $(36,41,42)$. From the aspect of age groups, children aged 5-9 years are at especially high risk, because they often play with dogs, both with their own and those of unknown owners. Apart from being the most often bitten group, children often hide the fact that they were bitten, so medical care may be given much later $(35,43)$. In an Indian study, the largest number of those bitten (47.5\%) were children aged 2-18 years. The largest number of bites to children occur during their outdoor activities (cycling, playing with a ball, running). The location of the bite is often associated with the age of the child, where younger children are more likely to have head injuries, while in the older children, lower extremities are mainly involved (44). The same data were obtained from a study conducted in Italy (45). The greatest number of bites is unprovoked, but they also occur at the time when the dog is feeding or caring for its puppies (42). Dog bites happen throughout the year, but the largest number of bites occurs in the summer, accounting for half of all bites (15).

\section{The Ethiopathogenesis of Bite Wound}

Microorganisms that exist in the canine oral cavity, together with saliva, enter the avulsionated tissue under pressure, immediately after the bite, and most commonly in an extremity-the hands, legs, head, or neck-whereby even a small number of bacteria with high virulence can cause an infection immediately after the bite. The force produced by the dog's eyeteeth during the bite varies among breeds, from $310 \mathrm{kPa}$ to almost 31,790 kPa in specially trained dogs (II). Along with the surface damage to the skin, muscles, tendons, blood vessels, and nerves are also 
often damaged. In deeper bite wounds, there is a risk of contamination from tetanus spores and consequent tetanus, especially if the wound is not treated adequately $(14,15)$. However, the greatest risk associated with dog bites is the risk of rabies in the case of an injury from a rabid animal (16). It is estimated that approximately 55,000 people die from rabies every year. There were no cases of human rabies in the researched areas of the FB\&H (18). Talan et al. (46) investigated bacterial microflora in 50 infected dog bite wounds in humans (Table 5). The most commonly isolated aerobic bacteria were Pasteurella (50\%), Streptococcus (46\%), Staphylococcus (46\%), Neisseria (32\%), and Corinebacterium (I2\%).

Bite wounds in people who have a poor immune status due to a previous illness, or who have been diagnosed with diabetes or a peripheral circulation disease, are often infected. In infected and fresh bite wounds (less than 8 hours after the bite and when the wounds were not clinically infected), it was found that they were polymicrobial with a wide combination of aerobic and anaerobic bacteria $(26,46,47)$.

\section{Clinical Symptoms of Bite Wounds}

Usually there is some damage to the skin, which may or may not be accompanied by bleeding. According to the research conducted by Talan et al. (46), of the 50 patients with bite wounds examined, $60 \%$ of the wounds were with only an eyeteeth imprint, $10 \%$ of the wounds had smaller perforations with lacerations, and $30 \%$ were combinations of both. Bruising occurs around the bite wound. Most infections were purulent but appeared without the abscess formation ( $58 \%$ ); followed by nonpurulent wounds with cellulitis, lymphangitis, or both (30\%); and abscesses (12\%). Limited and painful movements of the fingers and joints occur if the extremities are bitten, together with swelling and redness in the area of the injury (30).

\section{Basic Principles of a Bite Wound Treatment}

Although all bite wounds carry the risk of infection, abundant rinsing of the wound significantly reduces the risk of infection (4). At home, tap water and soap are used to rinse wounds. This is mostly done as self-help in the case of an adult or as first aid in the case of a child. After that, medical assistance should be sought. As the initial part of the bite wound treatment, it is necessary to evaluate the size and depth of the wound; the degree of damage to the surrounding tissue or the nerves; and any damage to the tendons, bones, and joints. As needed, complete wound inspection and debridement should be performed, if necessary, under local or general anesthesia, as well as the removal of any foreign bodies, most often the dog's teeth (II). All bite wounds should be thoroughly washed, first with $3 \%$ hydrogen peroxide $\left(\mathrm{H}_{2} \mathrm{O}_{2}\right)$ solution, followed by injection of povidone iodine solution (Isobetadine) using a $20 \mathrm{~mL}$ syringe (30). To reduce the potential risk of tetanus, it is necessary to postpone the wound closure wherever possible, or leave the wound open. It is necessary to lift and immobilize the wounded extremity to prevent edema (II). Superficial abrasive wounds should be thoroughly rinsed but not stitched. Patients are to be prescribed antibiotics. The antibiotic of choice is amoxicillin-clavulanate (Augmentin) (30). Patients should be assessed for the tetanus immunization status and treated with immunization or immunoglobulins if necessary. The necessity of rabies prophylaxis should be assessed on a case-by-case basis.

\section{Treatment of an Infection Resulting from a Dog Bite}

Although a relatively small number of bite wounds become infected, in larger wounds and in immunocompromized patients, it is necessary, as a measure of precaution, to prescribe antibiotics that are effective against Pasteurella, anaerobes and staphylococci, and these should be modified according to the culture of the results. Empirical imipenem with cilastatin (500 mg four times a day, intravenously) and clindamycin (900 mg four times a day, intravenously) are used for very severe infections. For patients with severe allergic reactions to penicillin, ciprofloxacin (400 mg twice a day, intravenously) plus metronidazole (500 mg three times a day, intravenously) replaces imipenem (II). The treatment of cellulitis usually lasts for 10-14 days, of tenosynovitis 3 weeks, of septic arthritis 4 weeks, and of osteomyelitis 6 weeks. The use of oral antibiotics in therapy when the C-reactive protein concentration is $<50 \mathrm{mg} / \mathrm{L}$ is a pragmatic approach, which has proved effective in practice (II).

\section{CONCLUSION}

In FB\&H, the presence of a large population of stray dogs is evident. Bites from stray dogs are more problematic than those of registered dogs and are becoming an increasing problem. Due to the report deficit on the number of stray dogs, dogs of known owners, and the bites of those from the Southeast Europe region, we did not have the opportunity to adequately compare the existing results from the FB\&H. The biggest risk for dog bites is actually the possibility of rabies or tetanus. Patients should be assessed for the tetanus immunization status and treated with immunization or immunoglobulins if necessary. In the FB\&H, for a number of years, no cases of rabies have been registered in humans, but occasionally, rabies is registered in animals, most often wild. That is why each individual is treated on a case-bycase basis, and the risk of rabies and the post-exposure protection are individually evaluated and determined. Dog bites are important for both the health and veterinary systems, and it is necessary to address this problem with the coordination of veterinary and health care services

Peer-review: Externally peer-reviewed.

Author contributions: Concept - M.K.; Design - N.H.A.; E.D.; Supervision M.K., Z.O., S.D.; Analysis and/or Interpretation - M.K., Z.O., S.D.; Literature Search - N.H.A., E.D.; Writing - M.K., Z.O., N.H.A., E.D.; Critical Reviews S.D.

Conflict of Interest: The authors have no conflicts of interest to declare.

Financial Disclosure: The authors declared that this study has received no financial support.

\section{REFERENCES}

I Simao NR, Borba AM, da Silva ALF, Vieira EMM, Carvalhosa AA, Bandeca MC, et al. Animal bite injuries to the face: A Case Report. $\mathrm{J}$ Int Oral Health 2013; 5: 68-72.

2. Dog-bite-related fatalities United States, 1995-1996. MMWR Morb Mortal Wkly Rep 1997; 46: 463-6.

3. Sacks JJ, Lockwood R, Hornreich J, Sattin RW. Fatal dog attacks, 1989-1994. Pediatrics 1996; 97: 891-5.

4. Presutti RJ. Prevention and Treatment of Dog Bites. American Family Physician 2001; 63: 1567-72.

5. Cavalcanti AL, Porto E, Santos BF, Cavalcanti CL, Cavalcanti AFC. Facial dog bite injuries in children: A case report. Int J Surgery Case Rep 2017; 4l: 57-60. [CrossRef] 
6. Schalamon J, Ainoedhofer H, Singer G, Petnehazy T, Mayr J, Kiss $\mathrm{K}$, et al. Analysis of dog bites in children who are younger than 17 years. Pediatrics 2006; II7: e374-9. [CrossRef]

7. Sacks JJ, Sattin RW, Bonzo SE. Dog Bite-Related Fatalities from 1979 Through 1988. JAMA 1989; 262: 1489-92. [CrossRef]

8. Chand-Meena M, Kumar-Naik SH, Mittal S, Band R. Fatal Dog Bite Injury - A Case Report. Int J Med Tox Forensic Med 20I5; 5: I64-7.

9. Karabeyaz K, Ayranci U. A forensic and Medical Evaluation of Dog Bites in a province of Western Turkey. J Forensic Sci 2014; 59: 505-9. [CrossRef]

10. Faydaci G, Tarhan F, Eryõldirim B, Tuncer M, Kuyumcuoglu U. Unexpected penile trauma; dog bite. Turk Uroloji Dergisi 2008; 34: II8-20.

II. Morgan M, Palmer J. Dog bites. BMJ 2007; 334: 4I3-7. [CrossRef]

12. Katica M, Obradovic Z, Gradascevic N, Hadzimusic N, Mujkanovic $R$, Mestric E, et al. Assessment of the Effect of Stray Dogs as a Risk Factor for the Health of Population in Certain Areas of Bosnia and Herzegovina. EJBS 2017; 4: 107-II.

13. Heath SE, Chomel BB. Risk factors, prevention and prophylaxis of dog bites for disaster response personnel in the United States. Prehosp Disaster Med 1998; 13: 58-62. [CrossRef]

14. Griego RD, Rosen T, Orengo IF, Wolf JE. Dog, cat and human bites: a review. J Am Acad Dermatol 1995; 33: 1019-29. [CrossRef]

15. Agarwal N, Reddajah VP. Epidemiology of dog bites: a community-based study in India. Trop Doct 2004; 34: 76-8. [CrossRef]

16. Takayama N. Rabies: apreventable but incurable disease. J Infect Chemother 2008; 14: 8-14. [CrossRef]

17. Ndon JA, Jach GJ, Wehrenberg WB. Incidence of dog bites in Milwaukee. Wis Med J 1996; 95: 237-4I.

18. Katica M, Gradascevic N, Hadzimusic N, Obradovic Z, Mujkanovic R, Mestric E, et al. Widespread of Stray Dogs: Methods for Solving the Problem in Certain Regions of Bosnia and Herzegovina. IJRG 2017; 5: 414-22.

19. Vučinić $M$, Đorđević $M$, Radenković-Damnjanović $B$, Janković LJ, Mirilović M. Bites to humans caused by stray and owned dogs in Belgrade. Acta Veterinaria (Belgrade) 2008; 58: 563-71. [CrossRef]

20. Lazzetti L. Anticipatory Guidance: Having a Dog in the Family. J. Pediatr Health Care 1998; 72: 73-9. [CrossRef]

21. Bradshaw JWS, Goodwin D, Lea AM, Whitehead SL. A survey of the behavioural characteristics of pure-bred dogs in the United Kingdom. Vet Rec 1996; 138: 465-8. [CrossRef]

22. Presutti RJ. Bite wound. Postgraduate Medicine 1997; I0I: 243-54. [CrossRef]

23. Anderson CR. Animal bites: guidelines to current management. Postgrad Med 1992; 92: 134-49. [CrossRef]

24. Rollof JG, Nordin-Fredriksson G, Holst E. Pasteurella multocida occurs in a high frequency in the saliva of pet dogs. Scand J Infect Dis 1989; 21: 583-4. [CrossRef]

25. Brook I. Microbiology of human and animal bite wounds in children. Pediatr Infect Dis 1987; 6: 29-32. [CrossRef]

26. Abrahamian FM, Goldstein JC. Microbiology of Animal Bite Wound Infections. Clin Microbiol Rev 20Il; 24: 231-46. [CrossRef]

27. Hennet PR, Harvey CE. Aerobes in periodontal disease in the dog: a review. J Vet Dent 1991; 8: 9-II.

28. Nieves MAP, Kinyon HJM, Riedesel DH. Bacterial isolates from plaque and from blood during and after routine dental procedures in dogs. Vet Surg 1997; 26: 26-32. [CrossRef]

29. Dameski P, Vnuk $\bigvee$, Habrun B, Kompes G. Bacterial Microflora in the Mouth of Dogs in Macedonia. Vet stn 2015; 46: 429-37.
30. Philipsen TEJ, Molderez C, Gys T. Cat and Dog bites. What to do? Guidelines for the treatment of cat and dog bites in humans. Acta chir belg 2006; 106: 692-5. [CrossRef]

31. Goldstein EJ. Bite wounds and infection. Clin Infect Dis 1992; 14: 6338. [CrossRef]

32. Allaker RP, Young KA, Langlois T, de Rosayro R, Hardie JM. Dental plaque flora of the dog with reference to fastidious and anaerobic bacteria associated with bites. J Vet Dent 1997; 14: 127-30.

33. Forsblom B, Sarkiala-Kessel E, Kanervo A, Vaisanen ML, Helander $\mathrm{M}$, Jousimies-Somer $\mathrm{H}$. Characterisation of aerobic gram-negative bacteria from subgingival sites of dogs- potential bite wound pathogens. J Med Microbiol 2002; 51: 207-20. [CrossRef]

34. Ganiere JP, Escande F, Andre G, Larra M. Characterization of Pasteurella from gingival scrapings of dogs and cats. Comp Immunol Microbiol Infect Dis 1993; 16: 77-85. [CrossRef]

35. Esposito S, Picciolli I, Semino M, Principi N. Dog and cat bite-associated infections in children. Eur J Clin Microbio Infect Dis 2013; 32 971-6. [CrossRef]

36. Slatina E, Obradović Z. Karakteristike najčešćih ugriza životinja i krpelja u Kantonu Sarajevo. NČ urgent medic HALO 20II; 17: 102-12.

37. Katica M, Mujkanović R, Imamović DŽ, Šaljić E, Kadić M, Kartal S, et al. Problems with Stray Dogs in Zenica-Doboj Canton and Sarajevo Canton. Oral Presentation. 4th Symposium of Agriculture, Veterinary, Forestry and Biotechnology with International Participation. Zenica, Bosnia and Herzegovina. 2006.

38. Vodopija R, Racz A, Pahor $Đ$. The incidence of jackal bites and injuries in the Zagreb anti rabies clinic during the 1995-2014 period. Acta Clin Croat 2016; 55: I5I-5. [CrossRef]

39. Syrmos N, Televantos A, Patiakas S, Kapoutzis N. Bite wound related infections in rural areas of Macedonia-Greece: consequences on overall health. Ann Gen Psychiatry 2010; 9(Suppl I): S97. [CrossRef]

40. Suddarshan MK, Mahendra BJ, Narayan DH. A community survey of dog bites, anti- rabies treatment, rabies and dog population management in Bangalore city. J Commun Dis 200l; 33: 245-51.

41. Shetty RA, Chaturvedi S, Singh Z. Profile of animal bite cases in Pune. J Commun Dis 2005; 37: 66-72.

42. Ischhpujani RL, Mala C, Veena M, Singh J, Bhardwaj M, Bhattacharya $D$, et al. Epidemiology of animal bites and rabies cases in India. A multicentric study. J Commun Dis 2008; 40: 27-36.

43. Fevre EM, Kabovo RW, Persson $V$, Edelsten M, Coleman PG, Cleaveland S. The epidemiology of animal bite injuries in Uganda and protections of the burden of rabies. Trop Med Int Health 2005; 10: 790-8. [CrossRef]

44. Reisner IR, Nance ML, Zeller JS, Houseknecht EM, Kassam-Adams N, Wiebe DJ. Behavioural characteristics associated with dog bites to children presenting to an urban trauma center. Inj Prev 20II; 17: 348-53. [CrossRef]

45. Ostanello F, Gherardi A, Caprioli A, La Placa L, Passini A, Prosperi S Incidence of injuries caused by dogs and cats treated in emergency departements in a major Italian city. Emerg Med J 2005; 22: 260-2. [CrossRef]

46. Talan DA, Citron FM, Abrahamian GJ, Moran E, Goldstein JC. Bacteriologic analysis of infected dog and cat bites. N Engl J Med 1999; 340: 85-92. [CrossRef]

47. Goldstein JC. Current concepts on animal bites: bacteriology and therapy. Curr Clin Top Infect Dis 1999; 19: 99-III. 